\title{
Determinant Factors for Compressed ERP Education for Stackable Credentialing
}

\author{
Ephrem Eyob \\ Virginia State University
}

This paper presents a case of a collaborative effort between a university, a two-year college, and partners within the Information Technology (IT) and Enterprise Integrated Information Technology including Enterprise Resources Planning (ERP) software companies to address the education and training of the workforce for ERP concentric positions. The courses in ERP that culminate with a certificate are seamlessly integrated into an accelerated associate degree that incorporates prior learning assessment with a competency-based framework. After completing the accelerated associate degree, students can continue the pathway for the bachelor's degree in information technology on a timeline that is reduced significantly. Data from OECD database that included OECD member countries including USA and selected countries outside the OECD membership was used to analyze factors that enhance training. The data was analyzed to identify important factors for successful training outcomes in compressed delivery format. Furthermore, the forty-one items from the database were factored using component factor analysis. The identified factors augment the Department of Labor competency model for training the workforce for $21^{\text {st }}$ century occupations.

Keywords: ERP, Competency Based Education (CBE), Prior Learning Assessment (PLA), Competency Model

\section{INTRODUCTION}

According to Federal Reserve Bank of Atlanta and Kansas City (Van Horn et. al. 2015), industries, employers and workers are faced with unrelenting global competitive environment with uncertainties and risks that are hard to manage. Many groups are concerned on the overarching issues and came with innovative solutions to address these multi-faceted problems. The 2008 great recession, only second in severity to the 1920s depression, resulted in tremendous disruption to the US economy, workers, businesses, government and educational institutions. Work force development training programs are growing by leaps and bound to make the US work force relevant and agile for industries' need.

Currently, the United States of America's information technology (IT) industries are facing severe shortage of well-trained and skilled workforce [see Table 1, for information and communication occupation outlook from 2016-2026]. To help mediate this shortage a comprehensive university and a two-year college developed a certificate program to educate and train trade displaced workers and veterans for careers in the IT industry specifically in Enterprise Resource Planning using SAP suite. The program also admits selected high school graduates and others career switchers with associate degrees. 
Normally, entry into the training requires six months of intensive training. Within the Trade Adjustment Assistance Community College and Career Training (TAACCCT) grant by the Department of Labor we leveraged coursework from a bachelor's program for a certificate program that is delivered via a cohort model and simultaneously linked to a hybrid competency based educational framework. No programs at our university or at the collaborating two- year college used competency-based credentialing before the project. We developed digitally delivered instructional components so that trainees can leverage job experience to accelerate completion of an associate degree that is aligned with the university's bachelor's programs. Students learn during their down times, meshing their self-paced studies with on-the job experience to progress up the credentials and career ladder. It also includes a work-reporting portfolio that allows continuous assessment of students' combined study and on-the-job experience and to document skills, thus allowing learners to opt out of classroom education for skills they have demonstrated in their studies and jobs. Finally, the ERP industry needs to develop professional standards in addition to the various short certification for specific software to allow employers to be confident that ERP certificate holders with business process and software system skills meet standard of knowledge, skills, and abilities of the profession. Table 1 shows the projected growth of computer and information technology and communication occupations from 2016 to 2016. Information security analysts, software developers, and computer and information research scientists are among the top projected growth area. ERP skills require any of the high growth occupations.

The objective of the grant was to ameliorate the impact of workers' dislocations due to trade economic, social, and lack of innovation in high demand training by using novel methods for transformative education and workforce development practice. To this end it helps in:

- Improving career opportunities for trade impacted laid-off displaced workers, veterans, high school graduates, especially those who face the greatest difficulties in the labor market;

- Meeting the needs of employers and society for a highly skilled and competitive workforce; and

- Delivering effective solutions relevant to educational institutions, businesses, nonprofit organizations and governments.

\section{TABLE 1 COMPUTER and INFORMATION TECHNOLOGY OCCUPATIONS}

\begin{tabular}{|l|c|}
\hline Occupation Category & Percent Growth \\
\hline Computer and Information Research Scientists & $19 \%$ \\
\hline Computer Network Architects & $6 \%$ \\
\hline Computer Programmers & $-7 \%$ \\
\hline Computer Support Specialists & $11 \%$ \\
\hline Computer Systems Analysts & $9 \%$ \\
\hline Database Administrators & $11 \%$ \\
\hline Information Security Analysts & $28 \%$ \\
\hline Network and Computer Systems & $6 \%$ \\
Administrators & $24 \%$ \\
\hline Software Developers & $15 \%$ \\
\hline Web Developers & \\
\hline
\end{tabular}

Source: Department of Labor 2016-2026 Computer and ITS Occupation Growth

The rest of the paper is structured with a review of related literature, explore the structure and flow of the training, methodology used to analyze data, lessons learned and finally conclusion. 


\section{LITERATURE REVIEW}

Learning skills in business process reengineering (BPR) and ERP implementation projects can enhance the dual capability of organizational changes with information technology (Davenport 1993; Esteves et al. 2002; Hammer and Champy 1993). Hepner and Dickson (2014) examined ERP research literature on potential benefits with outcomes from learning ERP system integration. ERP systems bring tremendous capabilities on cross-functional business processes, cooperation and coordination, and decision making within organizations (Kanthawongs, Wongkaewpotong and Daneshgar, 2010; Bradford, Vijayaraman and Chandra, 2003; Boykin and Martz Jr., 2004; Mandal and Flosi, 2012; Fedorowicz, et al. 2004). Several research initiatives tried to understand the skill requirements of ERP graduates (BecerraFernandez et al. 2000; Boyle and Strong 2006; Watson and Schneider 1999). The US Department of Education enables many types of prior learning assessment or Competency Based Education (CBE) programs. Due to variations in solution methodology, there is currently no standard definition for these educational methods. Hart M (1976) argues to use criteria to measure the accomplishment of targeted competencies as criterion-referenced, and the student acquires the competencies at their own rate. Much confusion exists in differentiating between the essential characteristics and implementation modes. Prior or competency-based education programs is organized by content knowledge and what the subject can do with the knowledge gained; content is organized according to what a student knows and can do, often referred to as a competency-based education. According to J.B King (2015) "for those of us who still think of educational levels as the number of years in school, semester hours taken, or postgraduate degrees accumulated, we have to realize that there is a major movement in higher education toward competency-based education.". CBE focuses on the learning objectives that result in students having mastered these competencies with emphasis on learning outcomes rather than length of learning time spent in a classroom.

Research shows that students with Prior Learning Assessment (PLA) credit had higher graduation rates, better persistence and lower time to degree completion, compared to students without PLA credits. The program aim was to create new PLA model within a new certificate program by using new technology and compress coursework pedagogy for PLA process and assessments. The students use online technology that allows students to view lectures or concept modules outside the classroom using the flipped model of pedagogy (Northrop, et al, 2015). The value-added compressed coursework is thought as a paradigm shift in the delivery of skills, knowledge that may result in attractive career opportunities for participants. Studies have shown that students taught in theoretical principles, processes and skills in isolation without practice do not transfer these skills and knowledge as well to their work environments.

\section{Training Structure}

The ERP (SAP) technical education followed the Department of Labor (DoL) competency model [see Figure 1, Ennis (2008) and Figure 2, Clark (2015)] as a guide by using the relevant competencies to structure and operationalize the training. Figure 2 depicts the relationship of education career-continuum, academic and workplace requirements from the general to the specific in a cascading manner. Each route ends is designed to enable with skills that prepares individuals for job readiness. Table 2 shows the breakdown of the three factors: foundational, industry specific, and occupation related skills. Furthermore, data collected from EOCD database using component factor analysis, (see Table 3), supports the model for training the workforce. The DoL competency model is divided into nine categories, with each category associated with specific competencies (see Table 2). The categories are stacked in a pyramid shape (Figure 1) with top of the pyramid associated with high specialization of skills and contents related to specific industries. 
FIGURE 1

US DOL COMPETENCY MODEL *

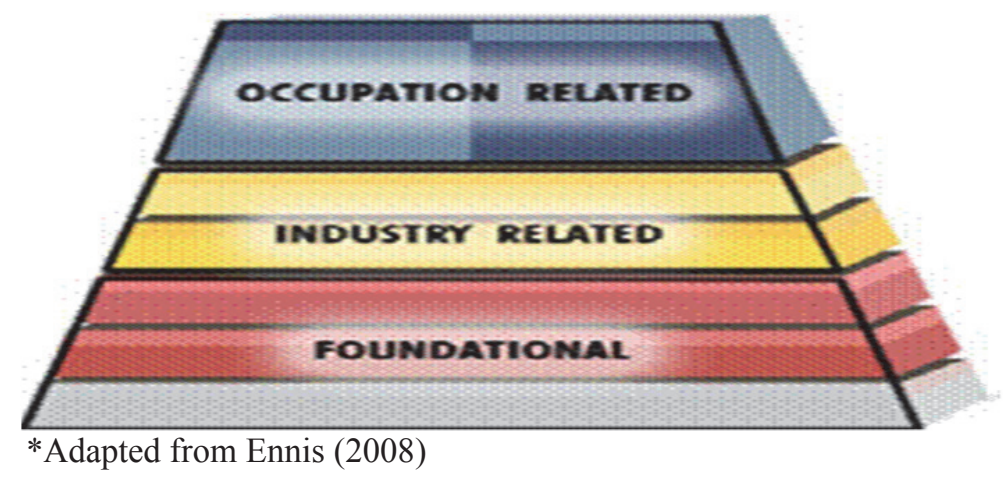

Below are the explanations and definitions of each categories:

a. Academic competencies include: Reading, writing, mathematics, science and technology, communication and interpersonal skills, critical and analytical thinking, active learning and basic computer skills.

b. The workplace competencies are such things as teamwork, adaptability and flexibility, customer focus, planning and organizing, creative thinking, problem solving and decision making, working with tools and technology, computer applications, scheduling and coordinating, checking examining and recording, and business fundamentals.

c. The industry-sector technical competencies are specified by industry sector.

d. Managerial competencies include staffing, informing, delegating, networking, entrepreneurship, supporting, budgeting, strategic planning, managing conflicts, developing organizational vision, monitoring and controlling resources.

e. Occupation specific requirements are requirements specified by the specific occupation.

TABLE 2

COMPETENCY CATEGORIES

\begin{tabular}{|l|l|l|}
\hline \multicolumn{1}{|c|}{$\begin{array}{c}\text { Occupation-Related } \\
\text { Competencies }\end{array}$} & \multicolumn{1}{|c|}{$\begin{array}{c}\text { Industry Related } \\
\text { Competencies }\end{array}$} & Foundational Competencies \\
\hline $\begin{array}{l}\text { Management } \\
\text { competencies }\end{array}$ & $\begin{array}{l}\text { Industry sector technical } \\
\text { competencies }\end{array}$ & Workplace competencies \\
\hline $\begin{array}{l}\text { Occupation specific } \\
\text { requirements }\end{array}$ & $\begin{array}{l}\text { Industry wide technical } \\
\text { competencies }\end{array}$ & Academic competencies \\
\hline $\begin{array}{l}\text { Occupation specific } \\
\text { technical competencies }\end{array}$ & & $\begin{array}{l}\text { Personal effectiveness } \\
\text { competencies }\end{array}$ \\
\hline
\end{tabular}

The ERP technology participants include students with various backgrounds, competencies, and experiences. Enterprise systems (ERP) are integrated software systems with many related modules that provide comprehensive functionality and business process integration across the firm (Davenport, 2000; Klaus et al., 2000). OECD data was used to analyze the requisite competencies to test/check the DoL model in the data analysis section. The two-year college measures the academic skills of students by pre and posttests. The purpose of testing is to assure the students meet the minimum institution requirements with foundation competencies and to be consistent with the accreditation of the institutions. The assessment provides direct evidence that a student has foundational competencies, have potential to 
master a specific academic area, or skills or that the student demonstrates a specific quality such as creativity, analysis or synthesis associated with the subject matter of the program. For instance, a test or an examination, projects, presentations, portfolio and presentation can be considered as a measure on the quality and depth of subject matter mastery.

\section{FIGURE 2 \\ CASCADING COMPETENCY MODEL *}
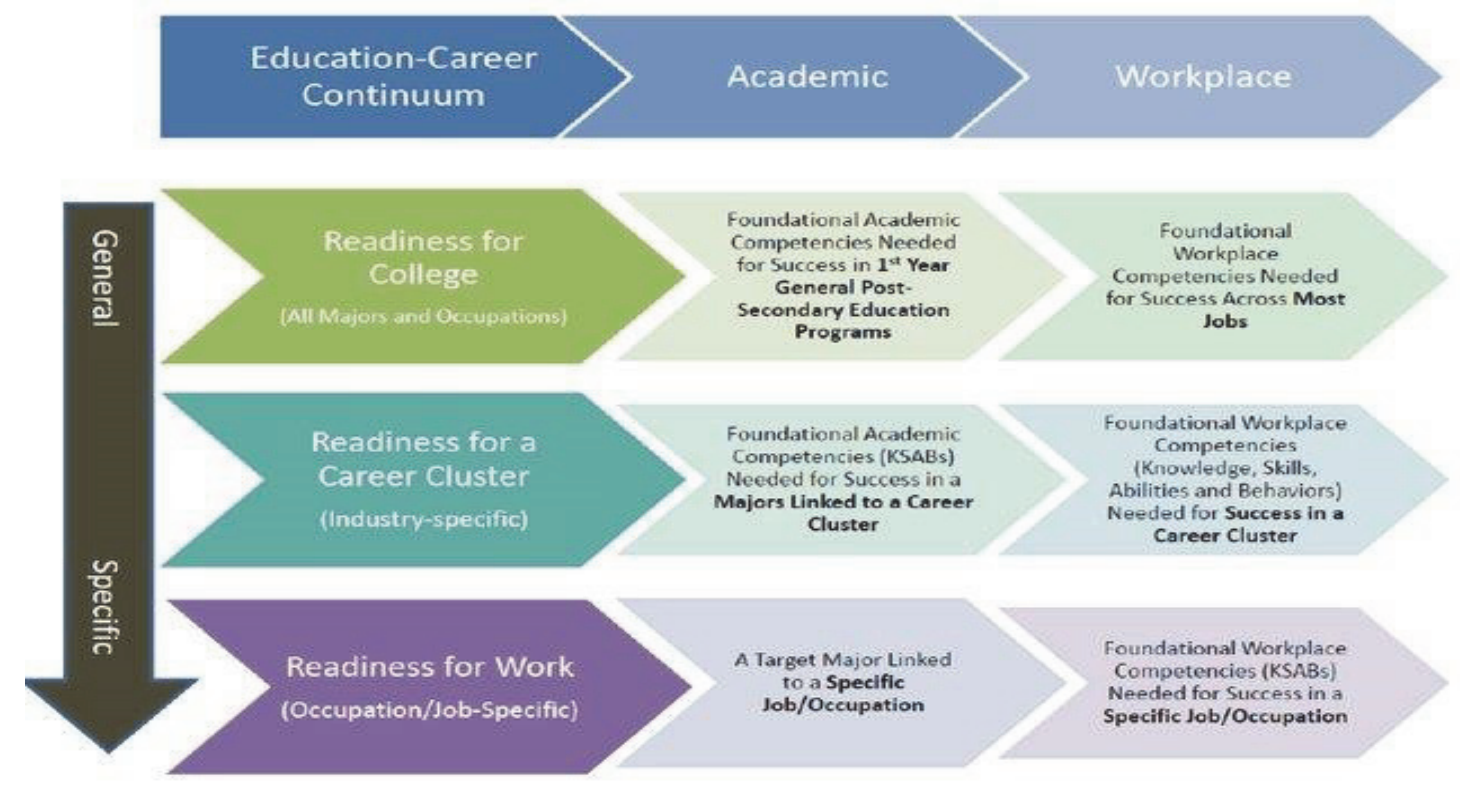

*Adapted from Clark (2015)

\section{Training Process}

Trainees were recruited from different backgrounds: the public at large, veterans and formers soldiers and laid-off workers due to economic trade adjustment issues. Potential candidates were processed at a regional Work Investment Board. If candidates meet the minimum academic qualifications, they were accepted for training either directly to the training program or took remedial development courses and then retested. The selected individuals possessed common traits such as suitability for training based on completion of high school or some college level courses or completion of AP courses with the ability to handle college level courses; or pass a battery of tests on mathematics, verbal and writing assessment tools. Students with potential but with some academic deficiencies enrolled at the two-year college to improve their college readiness by removing academic deficiencies. After completion of the remedial sessions, students enrolled at the four-year college and took sixteen credit hours comprised of theoretical and laboratory-based learning of technology related courses. Finally, students took the practical industrybased training of ERP based on SAP software for six months. After graduation from the certificate program, students had options to continue in the college level credentialing by attending the two-year college that included PLA on a case by case basis and enrolling in appropriate courses to earn an associate level degree or work in the enterprise integration industry or related occupation. For further education, students had an option to come back to the four-year college and take either online, hybrid or face-facecourses depending on their preferences. Those with two-year degree could matriculate in the four-year programs in any of the related disciplines including engineering technology or business tracks. Alternatively, students could transfer to other institutions. 


\section{METHODOLOGY}

The data source used for the study was the 2015 survey on labor skills measurements for thirty-nine countries that included Organization for Economic Co-Operation and Development (OECD) that includes the United States of America and a handful of non-member countries (OECD, 2015). Factor analysis was used to condense the key skills necessary for training in ERP skills and related employment. The data consisted of survey by professionals in the information and communication industry. The survey included forty-one items of skills deemed important for the workers in the information and communication industry. The range of measurement was from -1 to 1 . Negative values indicate unnecessary skills and positive value important skills.

TABLE 3

COMPONENT TOTAL VARIANCE

Initial Eigen Values $\quad$ Extraction Sums of Squared Loadings Rotation Sum Squared

\begin{tabular}{|l|l|l|l|l|l|l|l|}
\hline Component & Total & \%Variance & \%Cumulative & Total & \%Variance & \%Cumulative & Total \\
\hline Factor 1 & 35.575 & 86.769 & 86.769 & 35.575 & 86.769 & 86.769 & 22.226 \\
\hline Factor 2 & 2.385 & 2.385 & 5.816 & 92.585 & 2.385 & 5.816 & 11.534 \\
\hline Factor 3 & 2.107 & 2.107 & 5.138 & 97.723 & 2.107 & 5.138 & 6.307 \\
\hline
\end{tabular}

FIGURE 3

EIGEN VALUE for SIGNIFICANT COMPONENTS

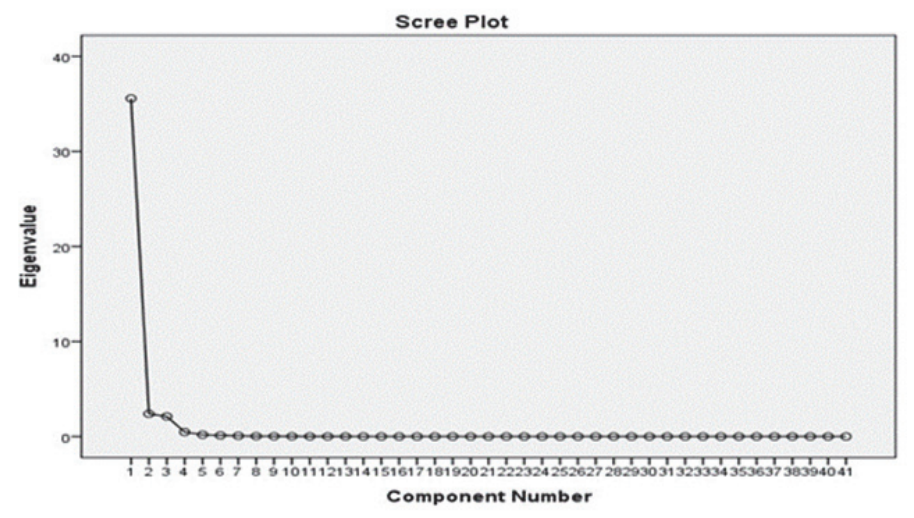

Figure 3 shows the varimax orthogonal rotation that produced three major factors with $97.7 \%$ cumulative variability for the three factors- the remaining $2.3 \%$ variability were ignored from the analysis. Items that had more than 0.5 loading were included in the factor analysis.

Cronbach's alpha reliability coefficient was used to test the reliability of the OECD survey data. The Cronbach's alpha ranged from 0.89 to 0.57 for the three factors (see Table 4). The closer the alpha coefficient to 1, the greater the internal consistency of items in the scale (Gleim and Gliem, 2003; Gopala et, al., 2011). 
TABLE 4

MODEL SUMMARY

\begin{tabular}{|c|c|c|c|}
\hline Component & Eigen Value & \%Variance & $\begin{array}{c}\text { Cronbach's } \\
\text { Alpha }\end{array}$ \\
\hline $\begin{array}{c}\text { Factor 1- Foundational } \\
\text { Competency }\end{array}$ & 35.75 & 86.77 & 0.89 \\
\hline $\begin{array}{c}\text { Factor 2 Industry Related } \\
\text { Competency }\end{array}$ & 2.365 & 5.82 & 0.60 \\
\hline $\begin{array}{c}\text { Factor 3 Occupational } \\
\text { Related Competency }\end{array}$ & 2.11 & 5.14 & 0.57 \\
\hline
\end{tabular}

TABLE 5

DoL FACTORS VS OECD MODEL RESULT FACTORS

\begin{tabular}{|c|c|c|c|c|}
\hline $\begin{array}{l}\text { OECD Data Analysis } \\
\text { Factor } 1 \\
\text { Foundational } \\
\text { Competencies }\end{array}$ & $\begin{array}{l}\text { DoL Model } \\
\text { Industry Related } \\
\text { Competencies }\end{array}$ & $\begin{array}{l}\text { OECD Data } \\
\text { Based Factor } 2 \\
\text { Industry Related } \\
\text { Competencies }\end{array}$ & $\begin{array}{l}\text { DoL Model } \\
\text { Occupation } \\
\text { Related } \\
\text { Competencies }\end{array}$ & $\begin{array}{l}\text { OECD Data based } \\
\text { Factor3 } \\
\text { Occupation } \\
\text { Related } \\
\text { Competencies }\end{array}$ \\
\hline $\begin{array}{l}\text { Negotiation } \\
\text { Social } \\
\text { Perceptiveness } \\
\text { System Analysis } \\
\text { Process Skills } \\
\text { Service Orientation } \\
\text { Decision Making }\end{array}$ & $\begin{array}{l}\text { Industry-sector } \\
\text { technical } \\
\text { competencies }\end{array}$ & $\begin{array}{l}\text { Programming } \\
\text { Installation } \\
\text { Equipment } \\
\text { Selection } \\
\text { Repairing }\end{array}$ & $\begin{array}{l}\text { Management } \\
\text { competencies }\end{array}$ & $\begin{array}{l}\text { Mgt Financial } \\
\text { Resources } \\
\text { Time } \\
\text { Management }\end{array}$ \\
\hline $\begin{array}{l}\text { Writing } \\
\text { Instructing } \\
\text { Reading } \\
\text { Comprehension } \\
\text { Critical Thinking } \\
\text { Complex Problem } \\
\text { Solving } \\
\text { Mathematics } \\
\text { System Skills }\end{array}$ & $\begin{array}{l}\text { Industry-wide } \\
\text { technical } \\
\text { competencies }\end{array}$ & $\begin{array}{l}\text { Technology } \\
\text { Design } \\
\text { Science } \\
\text { Technical Skills } \\
\text { Operational } \\
\text { Analysis } \\
\text { Equipment } \\
\text { Maintenance } \\
\text { Operation } \\
\text { Monitoring }\end{array}$ & $\begin{array}{l}\text { Occupation } \\
\text { specific } \\
\text { requirements: } \\
\text { Technical and } \\
\text { Knowledge } \\
\text { Competencies }\end{array}$ & $\begin{array}{l}\text { Operational control } \\
\text { Troubleshooting } \\
\text { Quality Control }\end{array}$ \\
\hline $\begin{array}{l}\text { Verbal/Speaking } \\
\text { Active Learning } \\
\text { Active Listening }\end{array}$ & & & & \\
\hline
\end{tabular}

The data analysis helped in tweaking and improving the delivery of the program. Principal component factor analysis was used to identify variables that can help strengthen the learning landscape. Varimax orthogonal rotation was utilized to identify whether the 41 variables were related to distinct factors that facilitate compressed learning pedagogy. The varimax orthogonal rotation resulted in three distinctive factors that explain $86.76 \%$ of the variance for the first factor foundational competencies; the second factor for industry related competencies of $5.82 \%$, and $5.14 \%$ for the third factor occupational related competencies (See Appendix A). Most of the variance approximately 87\% comes from foundational competencies. The cumulative variance for the three factors was 97.7 percent. Twenty-three items loaded on the first factor- foundational competencies, ten items for the second factor- industry 
related competencies, and four items for the third factor- occupational competencies. The Cronbach's Alpha for the first factor was $0.89,0.60$ for the second factor, and 0.57 for the third factor as shown in Table 4.

\section{Lesson Learned}

Unlike traditional delivery of education, competency-based learning provide credit for prior learning. There is a defined clear path line for indirect and direct assessment programs. Traditional labor market information does a poor job of capturing the demand within the industry. We plan to utilize in the future heavily direct assessment using the identified factors through this research and the DoL competency model to provide college credit for prior learning through our two-year college partner. Once the students complete their two-year degree, they continue their education in our university in any of the related degree programs. The advantages of using direct assessment instead of credit hours or number of hours instructed as a measure of student learning, direct assessment can directly assess what students know. The assessment measures what the student knows and what body of knowledge has been mastered. The body of knowledge may include subject matter content area and ability to synthesize the subject matter of the discipline. Typical direct measures include papers, team projects, examinations, and portfolio. The institution must create a mechanism how to convert the direct assessment into credit hours to seamlessly provide credit in a given curriculum for degree matriculation. It is paramount that institutions develop clear policies on how direct assessment measure is converted into credit hours of a course.

We used digital-delivered instructional components so that trainees can learn during their down times, meshing their self-paced studies with on-the-job experience to progress up the credentials and career ladder. This included a work-reporting portfolio that allowed continuous assessment of students' combined study and on-the-job experience and to document skills, thus allowing our learners to opt out of classroom education for skills they've demonstrated in their studies and jobs. Finally, the ERP industry needs to develop professional standards to allow employers to be confident that ERP certificate holders have the necessary skills, knowledge and meet an accepted level of training to be employed in the industry. The data analyzed using the OECD source will help mitigate the gap.

\section{SUMMARY AND CONCLUSIONS}

This research makes an important practical contribution as it validates the U.S. Department of Labor competency model using OECD's countries survey data for information and communication industry through exploratory factor analysis. Although the items identified through the analysis don't match 100 percent with the DoL competency model, there is a large congruency between the dimensions listed in the DoL model and the factor analysis. The DoL model was the foundation for our training project for ERP skills in our institution for successful workforce development in ERP skills and implementation concepts. Besides learning integrating business processes with ERP concepts, the three factors were condensed from forty-one skill sets identified as necessary by survey respondents for information and communication technology industry. The three factors are foundational, industry and occupational dimensions. The foundational encompass basic skills such as writing, reading, mathematics, team-work, managerial acumen, social perceptiveness, time management, process skills, solving complex problems and critical thinking. The industry factors are mostly technical that includes skills in programming, systems analysis and design, control and operational, repairing, equipment selection and scientific approach to problem solving. Finally, the third factor are occupational specific to management, troubleshooting, quality control and operation control. The innovative approach to train dislocated workers and veterans focused on selecting students based on their potential to fit the important factors for information and communication industry skills specifically in this case attention to organization business transformation process, interpersonal skills and not exclusively on technical issues. Our approach also encouraged students to learn "more" by doing and credited their work experience through PLA. Finally, the project's goal was to increase trainees' satisfaction with the learning experience for practical, multidisciplinary approach to teaching ERP skills. The learning experience allowed trainees to learn inter- 
personal team approach to complex problem solving, increase their managerial acumen, and manage staff and deal with conflicts. Future research may include to test the factors using structural equation modeling using formal hypothesis if the data fit significantly for the theory of compressed education for training the workforce.

\section{REFERENCES}

Baider, A., Choitz, V., Duke-Benfield, A. E., Foster, M., Harris, L., Lower-Basch, E., \& Ridley, N., et al. (2010). Funding career pathways and career pathway bridges: A federal policy toolkit for states. Center for Law and Social Policy (CLASP).

Becerra-Fernandez, I., Murphy, K., \& Simon, S. (2000). Integrating ERP in the Business School Curriculum", Association for Computing Machinery, Communications of the ACM, 43(4), 39-41.

Boykin, R.F., \& Martz, J.W.B. (2004). The Integration of ERP into a Logistics Curriculum: Applying a System Approach. Journal of Enterprise Information Management, 17(1), 45-55.

Boyle, T.A., \& Strong, S.E. (2006). Skill Requirements of ERP Graduates. Journal of Information Systems Education, 17(4), 403-412.

Brigham, C., \& Klein-Collins, R. (2010). Availability Use and Value of Prior Learning Assessment within Community Colleges. CAEL.

Bureau of Labor Statistics. (2016). Occupational Outlook Handbook. Retrieved September 23, 2018, from https://www.bls.gov/ooh/computer-and-informationtechnology/home.htm

Clark, H. (2015). Building a Common Language for Career Readiness and Success: A Foundational Competency Framework for Employers and Educators. CT working papers document preliminary research.

Competency Based Education Experiment Guide: Introduction. (2015). Retrieved October 5 2018, from https://experimentalsites.ed.gov/exp/pdf/CompetencyBasedEducationGuide.pdf

Davenport, T. H. (2000). Mission Critical: Realizing the Promise of Enterprise Systems. Harvard Business School Press, Cambridge, Mass.

Davenport, T. (1993). Process Innovation: Reengineering Work through Information Technology. Harvard School Press: Boston

Ennis, M. (2008). Competency Models: A Review of the Literature and the Role of the Employment and Training Administration (ETA). Retrieved from https://wdr.doleta.gov/research/FullText_Documents/Competency\%20Models\%20$\% 20$ A $\% 20$ Review $\% 20$ of $\% 20$ Literature $\% 20$ and $\% 20$ the $\% 20$ Role $\% 20$ of $\% 20$ the $\% 20$ Employment $\% 20$ and\%20Training\%20Administration.pdf

Esteves, J., Pastor, J., \& Casanovas, J. (2002). Monitoring Business Process Redesign in ERP Implementation Projects. Proceedings of the Americas Conference on Information Systems (AMCIS), Dallas, TX

Fedorowicz, J., Gelinas Jr, U. J., Usoff, C., \& Hachey, G. (2004). Twelve Tips for Successfully Integrating Enterprise Systems across the Curriculum. Journal of Information Systems Education, 15(3), 235-244.

Gliem, J. A., \& Gliem, R. R. 92003) Calculating, Interpreting, and Reporting Cronbach's Alpha Reliability Coefficient for Likert-Type Scales. Midwest Research to Practice Conference in Adult, Continuing, and Community Education.

Gopalan, S., Cerikh, M., \& Khojaste, M. (2011). An exploratory Investigation of the Impact of National Culture on Motivation and Learning Styles of B-Schools: Students from India. Journal of Internal Education Research, 7(1), 53-60.

Hammer, M., \& Champy, J. (1993). Reengineering the Corporation: A Manifesto for Business Revolution. HarperCollins: New York.

Hart, M. (1976).Competency Based Education. Journal of the American Dietetic Association, 69(6), 616620. 
Hepner, M., \& Dickson, W. (2013). The Value of ERP Curriculum Integration: Perspectives from the Research. Journal of Information Systems Education, 24(4), 309-326.

Jaggars, S. (2011). Online Learning: Does It Help Low-Income and Underprepared Students? Community College Research Center.

Kane, M., Berry, S., Goslin, D., \& Meltze, A. (1990). Secretary's Commission on Achieving Necessary Skills Identifying and Describing the Skills Required by Work, September 14, 1990.

Kanthawongs, P., Wongkaewpotong, O., \& Daneshgar, F. (2010). A comparative study of students' learning outcome in non-web-based and web-based ERP- simulated classroom environments. International Journal of Business Research, 10(2).

Klaus, H., Rosemann, M., \& Gable, G. G. (2000). What is ERP? Information Systems Frontiers, 2(2), 141-162.

King, III, S. B. (2015). Competency-Based Education. Journal American Cardiovascular Intervention, 8(2), 374- 375.

Maguire, S., Freely, J., Clymer, C., Conway, M., \& Schwartz, D. (2010). Tuning in to local labor markets: Findings from the sectoral employment impact study. Private/Public Ventures. Retrieved January 19, 2019, from https://www.issuelab.org/resource/tuning-in-to-local-labormarkets-findings-from-the-sectoral-employment-impact-study.html

Mandal, P., \& Flosi, A. (2012). Horizontal integration of courses through SAP: Implementation in a business school. International Journal of Business Information Systems, 9(3), 343-355

Northrup, S. G., \& Burke, J. J. (2015, June). A Hybrid Approach to a Flipped Classroom for an Introductory Circuits Course for all Engineering Majors. (2015). Paper presented at 2015 ASEE Annual Conference and Exposition, Seattle, Washington. 10.18260/p.23398

OECD. (2015). Retrieved September 3, 2018, from https://stats.oecd.org/

Pemberton, C. L. A., \& Akkary, R. K. (2010, June). A Cohort, is a Cohort, is a Cohort...Orisit? Journal of Research on Leadership Education, 5(68).

Peslak, A. R. (2005). A Twelve-Step, Multiple Course Approach to Teaching Enterprise Resource Planning. Journal of Information Systems Education, 16(2), 147-156.

U.S. Department of Education. (2019, March). Retrieved from http:/www.ed.gov/oii-news/competencybased-learning-orpersonalized-learning

USDOL Competency Model Clearinghouse. (n.d.). Retrieved from http://www.careeronestop.org/CompetencyModel

Van Horn, G., Edwards, T., \& Green, T (2015). Transforming U.S. Workforce Development Policies for the 21st Century. Retrieved from https:/www.kansascityfed.org/publications/community/transformworkforce/about

Watson, E., \& Schneider, H. (1999). Using ERP Systems in Education. Communication of the Association for Information Systems, 1(9). 


\section{APPENDIX A \\ COMPONENT FACTOR ANALYSIS}

Factor $1=$ Foundational Competencies, Factor $2=$ Industry Related Competencies, and

Factor 3= Occupation Related Competencies

\begin{tabular}{|c|c|c|c|c|c|c|c|}
\hline Skill Set & $\begin{array}{c}\text { Factor } \\
1\end{array}$ & Mean & SD & Skill Set & $\begin{array}{c}\text { Factor } \\
1 \\
\end{array}$ & Mean & SD \\
\hline System Evaluation & 0.900 & 0.241 & 0.130 & Process Skills & 0.826 & 0.100 & 0.106 \\
\hline Negotiation & 0.895 & 0.073 & 0.084 & Instructing & 0.823 & 0.077 & 0.082 \\
\hline $\begin{array}{l}\text { Social } \\
\text { Perceptiveness }\end{array}$ & 0.866 & 0.091 & 0.102 & Writing & 0.822 & 0.264 & 0.149 \\
\hline Social Skills & 0.862 & 0.157 & 0.091 & $\begin{array}{c}\text { Service } \\
\text { Orientation }\end{array}$ & 0.822 & 0.077 & 0.088 \\
\hline Persuasion & 0.858 & 0.081 & 0.095 & Instructing & 0.821 & 0.077 & 0.082 \\
\hline Time Management & 0.856 & 0.090 & 0.097 & $\begin{array}{c}\text { Active } \\
\text { Listening }\end{array}$ & 0.816 & 0.120 & 0.127 \\
\hline Monitoring & 0.846 & 0.200 & 0.089 & System Skills & 0.816 & 0.093 & 0.101 \\
\hline Learning Strategies & 0.840 & 0.256 & 0.105 & $\begin{array}{l}\text { Active } \\
\text { Learning }\end{array}$ & 0.811 & 0.257 & 0.127 \\
\hline $\begin{array}{l}\text { Verbal/Speaking } \\
\text { Ability }\end{array}$ & 0.840 & 0.234 & 0.128 & $\begin{array}{l}\text { Critical } \\
\text { Thinking }\end{array}$ & 0.805 & 0.241 & 0.123 \\
\hline $\begin{array}{l}\text { Complex Problem } \\
\text { Solving }\end{array}$ & 0.793 & 0.217 & 0.118 & $\begin{array}{l}\text { Decision } \\
\text { Making }\end{array}$ & 0.754 & 0.234 & 0.128 \\
\hline $\begin{array}{l}\text { Reading } \\
\text { Comprehension }\end{array}$ & 0.792 & 0.283 & 0.166 & Mathematics & 0.740 & 0.165 & 0.115 \\
\hline System Analysis & 0.755 & 0.230 & 0.131 & & & & \\
\hline
\end{tabular}




\begin{tabular}{|l|c|c|c|c|c|c|}
\hline Skill Variable & $\begin{array}{c}\text { Factor } \\
\mathbf{2}\end{array}$ & Mean & SD & $\begin{array}{c}\text { Factor } \\
\mathbf{2}\end{array}$ & Mean & SD \\
\hline Programming & 0.933 & .0713 & .086 & 0.933 & .0713 & .086 \\
\hline Technology Design & 0.876 & .0637 & .055 & 0.876 & .0637 & .055 \\
\hline Science & 0.817 & 0.195 & 0.094 & 0.817 & 0.195 & 0.094 \\
\hline Installation & 0.748 & 0.008 & 0.01 & 0.748 & 0.008 & 0.01 \\
\hline Equipment Selection & 0.741 & 0.017 & 0.020 & 0.741 & 0.017 & 0.020 \\
\hline Technical Skills & 0.712 & 0.017 & 0.035 & 0.712 & 0.017 & 0.035 \\
\hline Repairing & 0.706 & 0.011 & 0.018 & 0.706 & 0.011 & 0.018 \\
\hline $\begin{array}{l}\text { Operational } \\
\text { Analysis }\end{array}$ & 0.694 & 0.061 & 0.073 & 0.694 & 0.061 & 0.073 \\
\hline $\begin{array}{l}\text { Equipment } \\
\text { Maintenance }\end{array}$ & 0.665 & 0.011 & 0.019 & 0.665 & 0.011 & 0.019 \\
\hline $\begin{array}{l}\text { Operation } \\
\text { Monitoring }\end{array}$ & 0.501 & 0.043 & 0.052 & 0.501 & 0.043 & 0.052 \\
\hline
\end{tabular}

\begin{tabular}{|l|c|c|c|}
\hline Skill Variable & Factor 3 & Mean & SD \\
\hline Management Financial Resources & 0.912 & 0.039 & 0.060 \\
\hline Operations Control & 0.956 & 0.020 & 0.034 \\
\hline Troubleshooting & 0.954 & 0.032 & 0.042 \\
\hline Quality Control & 0.781 & 0.050 & 0.057 \\
\hline
\end{tabular}

